Faculdade de Ciências Econômicas UFRGS
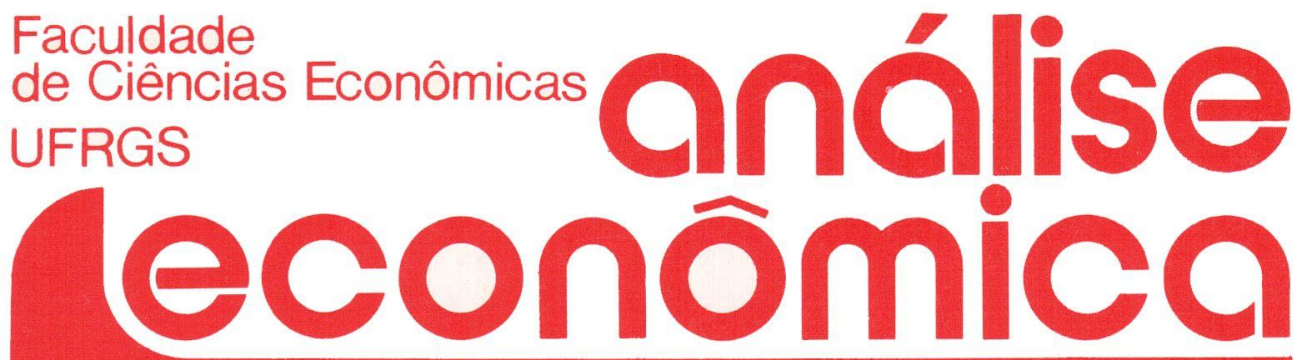

- apResentaÇ̃o à "ANálise simples da MAXIMIZAÇÂO DO BEM-ESTAR" DE FRANCIS BATOR

João Rogério Sanson

- UMA ANÁlise SIMPLES da MAXIMIZAÇÃo do BEM-ESTAR

Francis M. Bator

- O Regime de câmbio flutuante numa ETAPA DE TRANSICÃO

Francisco Eduardo Pires de Souza

- AgREgAdos monetÁRIOS, NIVEL DE RENDDA NOMINAL, TAXA DE INFLAÇÃO: UMA ANÁLISE DA CAUSALIDADE NO BRASIL, 1972 A 1987

Divanildo Triches

- A EXPlosão de CONSUMO do CRUzAdo Marcelo Cortes Neri

- METOdologia de PLANEJAMENTO do SETOR ELÉTRICO: QUESTŐES DOS ANOS 90

João Lizarolo de Araújo

Adilson de Oliveira

- CONCENTRAÇÃo INDUSTRIAL NO BRASIL SEGUNDO OS CENSOS, 1907-1980

Olimpio J. de Arrouxelas Galvão

- O VAlor, A RIQUEza e A TEORIA DE SMITH Reinaldo A. Carcanholo

- O "ESTADO ESTACIONÁRIO" e A ECONOMIa CLÁSSICA

Gentil Corazza

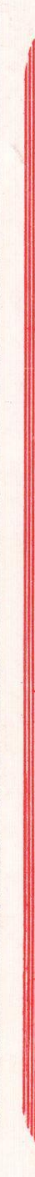
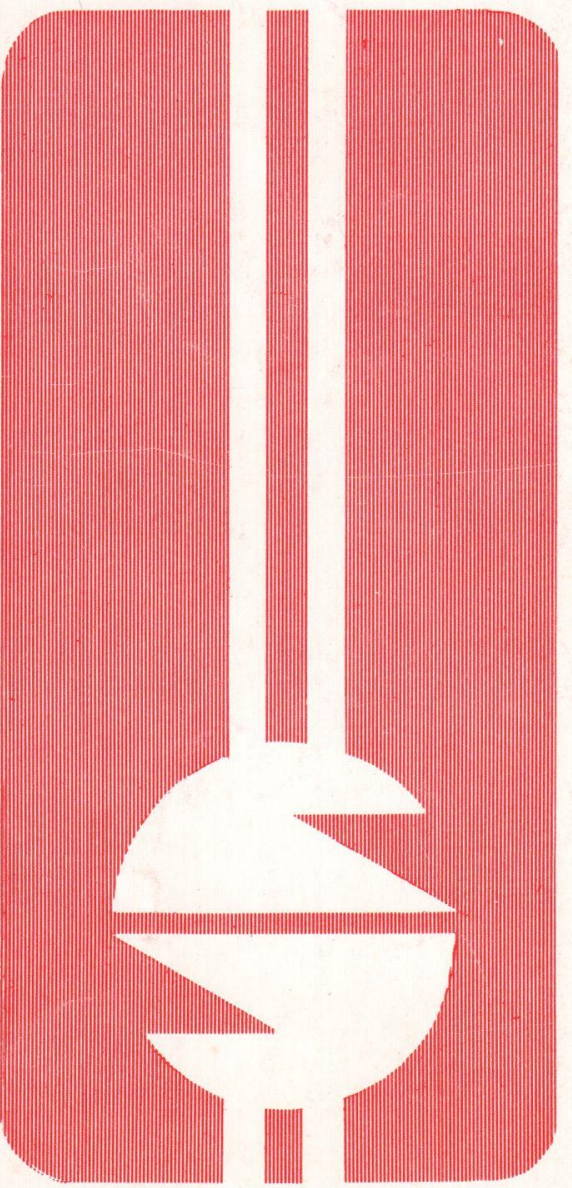
UNIVERSIDADE FEDERAL DO RIO GRANDE DO SUL

Reitor: Prof Tuiskon Dick

FACULDADE DE CIÊNCIAS ECONÔMICAS

Diretora: Prof ${ }^{\text {a }}$ Yeda Rorato Crusius

CENTRO DE ESTUDOS E PESQUISAS ECONÔMICAS

Diretor: Reinaldo Ignacio Adams

DEPARTAMENTO DE CIÊNCIAS ECONÔMICAS

Chefe: Prof. Pedro Cezar Dutra Fonseca

CURSO DE PÓS-GRADUAÇĀO EM ECONÔMIA

Coordenador: Prof. Nali de Jesus de Souza

CURSO DE PÓS-GRADUAÇĀO EM ECONOMIA RURAL

Coordenador: Prof. Atos Freitas Grawunder

CONSELHO EDITORIAL: Achyles Barcelos da Costa, Aray Miguel Feldens, Atos Freitas Grawunder, Carlos Augusto Crusius, Ernani Hickmann, João Rogério Sanson, Juvir Luiz Mattuella, Maria Imilda da Costa e Silva, Nali de Jesus de Souza, Nuno Renan Lopes de Figueiredo Pinto, Otilia Beatriz Kroeff Carrion, Otto Guilherme Konzen, Paulo Alexandre Spohr, Pedro Cezar Dutra Fonseca, Reinaldo Ignacio Adams, Roberto Camps Moraes, Valter José Stülp, Yeda Rorato Crusius, David Garlow (Wharton Econometrics Forecasts Association, E.U.A.), Edgar Augusto Lanzer (UFSC), Eleutério F. S. Prado (USP), Fernando Holanda Barbosa (FGV/RJ), Gustavo Franco (PUC/RJ), Joaquim Pinto de Andrade (UNB), Juan H. Moldau (USP), Werner Baer (Univ. de Illinois, E.U.A.)

COMISSÃO EDITORIAL: Atos Freitas Grawunder, Pedro Cezar Dutra Fonseca, Reinaldo Ignacio Adams e Roberto Camps Moraes.

EDITOR: Nali de Jesus de Souza

SECRETARIA: Maria Ivone de Mello (normalização), Vanete Ricacheski (revisão de textos), Zélide Bregalda (Secretária)

FUNDADOR: Prof. Antônio Carlos Santos Rosa

Os materiais publicados na revista Análise Econômica são de exclusiva responsabilidade dos autores. $\dot{E}$ permitida a reprodução total ou parcial dos trabalhos, desde que seja citada a fonte.

Aceita-se permuta com revista congêneres. Aceitam-se, também, livros para divulgação, elaboração de resenhas ou recensões.

Toda correspondência, material para publicaçāo (vide normas na $3^{\mathrm{a}}$ capa), assinaturas e permutas devem ser dirigidos ao seguinte destinatário:

PROF. NALI DE JESUS DE SOUZA

Revista Análise Econômica

Av. João Pessoa, 52

90.040 - PORTO ALEGRE (RS), BRASIL

Telefones: (0512) 28.1633; 24.6022; 26.0012 - Ramals 3440 e 3507

FAX: (0512) 25.5253 


\title{
CONCENTRAÇÃO INDUSTRIAL NO BRASIL SEGUNDO OS CENSOS, 1907-1980*
}

\author{
Olimpio J. de Arrouxelas Galvão**
}

\begin{abstract}
SINOPSE
Este trabalho utiliza os Censos industriais de 1907 a 1980 para examinar a evoluçāo da concentração espacial da indústria no Brasil. Em suas várias seções, o trabalho comenta sobre a situação das regiỏes brasileiras na entrada do século $X X$; analisa o grau de concentração e dispersão da indústria no inicio do século, à luz do Censo Industrial de 1907, discutindo também a posição do Brasil Industrial ern termos de outros setores e de outros palses; descreve a evolução histórica da concentração da indústria por macrorregiōes e por Estados selecionados; e conclui com algumas considerações sobre as implicaçōes de um processo de industrializaçăo extremamente polarizador, e concentrado espacialmente em reduzida área do território nacional.
\end{abstract}

\section{INTRODUÇÃO}

O Brasil é talvez o país que apresenta o maior índice de concentração territorial da produção manufatureira em todo o mundo. Em 1980 - último ano para o qual no presente momento existem informações censitárias - 73 por cento do valor da produção industrial se encontravam concentrados numa das cinco macrorregiōes do pais, o Sudeste, regiāo onde se localizam quatro das 26 unidades federadas da nação, e que corresponde a menos de 11 por cento da sua área total. Em uma única unidade da Federação - o Estado de São Paulo - onde vivia em

* Professor do Departamento de Economia e do PIMES da Universidade Federal de Pernambuco.

** Trabalho apresentado no $18^{\circ}$ Encontro Nacional de Economia da ANPEC, realizado em Brasflia, entre 03 e 06/12/90.

ANÁLISE ECONÔMICA

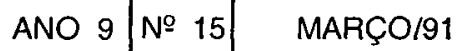

p.143-181 
$19801 / 5$ da população brasileira e cuja dimensão territorial representa 2,9 por cento da superficie nacional, concentravam-se $53,5 \%$ da produção manufatureira do País.

Este trabalho se propõe a examinar a evolução da concentração espacial da indústria no Brasil, no período de 1907 a 1980. Utilizando como principal fonte de informaçōes os dados dos censos industriais, desde o levantamento pioneiro do Centro Industrial do Brasil, de 1907, até o último censo da Fundação IBGE, de 1980, seu propósito é o de descrever os traços mais importantes do processo da industrialização brasileira, no que diz respeito às principais mudanças ocorridas na distribuição geográfica da produção industrial, seja em nivel regional, seja em nível de estados selecionados de cada região.

\section{ANTECEDENTES: AS REGIÕES BRASILEIRAS NA ENTRADA DO SÉCULO XX}

Examinando-se o desenvolvimento da economia brasileira de uma perspectiva espacial, uma caracteristica marcante pode ser detectada: da época colonial até as primeiras três décadas do século atual, a expansão da economia nacional ocorreu em partes diferentes do País, em larga medida em função das condições da demanda externa por exportáveis. A partir da segunda metade do século XIX - restringindo-se a análise, aqui, a um período mais recente - o Norte exportava borracha; o Nordeste, açúcar, algodão, fumo e cacau; o Sudeste, café; e o Sul erva-mate, couros e peles. A essas bases de exportação, o Brasil deve a emergência de suas economias regionais, que evoluíam, historicamente, em ritmos diferentes, de acordo com o maior ou menor dinamismo dos mercados externos e de acordo, também, com os maiores ou menores efeitos multiplicadores que os setores de exportação exerciam sobre outras atividades econômicas de cada região.

Durante a maior parte do séc. XIX, a escravidão era generalizada em todo o País e constituía a forma predominante de trabalho organizado. Os escravos, todavia, representaram, sempre, uma pequena proporção da população total. No ano da Independência, a população livre no Brasil era estimada em cerca de 70 por cento, ou mais, de um total de 4,3 milhões de habitantes. Em 1872, quando o primeiro censo demográfico oficial foi realizado, os escravos representavam menos de 15 por cento de uma população total de 10,1 milhões, e esta proporção declinou persistentemente até a abolição final, em 1888. A grande maioria 
da população livre, que foi forçada, com o passar do tempo, a assumir o status de moradores ou agregados da grande propriedade, não estava engajada na produção para o mercado externo, mas na produção de alimentos para o autoconsumo. No que diz respeito à terra, apenas uma diminuta proporção era efetivamente utilizada para fins produtivos, e até mesmo nas zonas de plantation, era reduzida a área economicamente utilizada. Na virada do século XIX, de acordo com estimativas de contemporâneos, não mais do que cinco ou seis por cento da terra agricultável nas áreas da produção açucareira em Pernambuco - na época o maior produtor de açúcar do Brasil - estavam sob cultivo (Cf. Levine, 1978, p.24; Galloway, 1968, p.290, e 1971; e Eisenberg, 1974). No Estado de São Paulo - também na época o maior produtor de café do Pais - foi estimado que as fazendas cafeeiras jamais chegaram a cobrir mais do que 15 por cento da terra agricultável, esse limite aplicando-se até mesmo às zonas mais prósperas do oeste paulista (cf. Holloway, 1980, p.28).

A maior parte das terras, cultivada ou não, já estava, como é sabido, apropriada por um pequeno número de grandes proprietários. Como esse regime de apropriação e uso da terra bloqueou, durante todo o século XIX, o avanço social da vasta maioria da população livre nas áreas rurais do País, é fácil compreender porque o principal, senão quase único impulso para o crescimento da economia, advinha de mercados externos. É legítimo concluir, assim, que o desenvolvimento da economia brasileira foi essencialmente do tipo induzido por exportaçōes - em contraste com outro tipo de crescimento, centrado essencialmente no desenvolvimento da produção para o mercado doméstico, como foram os casos do Canadá e dos Estados Unidos, no séc. XIX - mesmo considerando-se a importância que as exportações exerceram na evolução da economia desses paises (Cf. Baldwin, 1956, North, 1959, Watkins, 1963, Taylor, 1968, e Kravis, 1970).

Muitas outras atividades econômicas importantes, desenvolvidas em várias partes do Brasil, não estavam diretamente voltadas para produção de exportáveis, a saber. as vastas áreas de criação pecuária dos sertões nordestinos; as províncias centrais do Pais, de modo especial as grandes fazendas de Minas Gerais; e as áreas produtoras de carnes e cereais das provincias sulinas. Todas essas atividades, todavia, estavam indiretamente conectadas com as zonas produtoras de exportáveis, de diversas-maneiras, através, por exemplo, do fornecimento de matériasprimas para o acondicionamento de exportações, e do abastecimento 
das plantations para alimentação dos escravos e também da população; livre e escrava, das principais cidades portuárias do País.

Se se adicionam a essas considerações a imensidão do território nacional, a escassa e desigual distribuição espacial da população e as enormes dificuldades de comunicações internas, não é de estranhar porque, ao se iniciar o século $X X, \circ$ Brasil era não mais que um imenso arquipélago de ilhas humanas: politicamente unificadas mas longe de constituírem uma verdadeira e integrada economia nacional.

O resultado, tanto da relativa segregação econômica das regióes brasileiras quanto da sua dependência de uns poucos produtos exportáveis, foi a emergência de uma multiplicidade de mercados espacialmente autônomos, essa pluralidade de mercados regionais isolados constituindo uma das caracteristicas mais marcantes da economia brasileira até passado recente (cf. Galvão, 1988).

Em várias partes do País, em maior grau em algumas, em menor em outras, as bases regionais de exportações (no caso das economias sulinas, mais as exportações para os mercados nacionais do que para os externos) estimulavam o crescimento de atividades domésticas, inclusive industriais, que se destinavam ao atendimento das necessidades locais de consumo, ou, no máximo, regionais. Essas indústrias, nos seus primórdios e durante longo período de sua expansão, produziam um conjunto diversificado de bens, especialmente aqueles que não podiam ser importados do exterior, seja pelos altos custos do transporte, seja por causa de proteçảo tarifária, ou por outras restrições às importações, decorrentes da relativa escassez de divisas que sempre esteve presente na evolução da economia brasileira.

A quase completa ausência de concorrência inter-regional, por seu turno, levou a que muitas indústrias se instalassem em todos os lugares onde havia algum adensamento populacional expressivo, fazendo com que o Pais desenvolvesse, em distintas partes do território nacional, estruturas econômicas semelhantes em muitas linhas de produção. Desse modo, a divisão do trabalho, que ia se implantando em cada região, seja na agricultura, seja na indústria, era determinada pela possibilidade pura e simples da produção dos bens para os quais havia uma demanda, e não em função das diferenças regionais de vantagens absolutas ou comparativas. Isto significou, portanto, que a especialização regional, que ocorria até as primeiras décadas do século atual, era fundamental- 
mente ditada pela disponibilidade de recursos locais (especialmente recursos naturais), e não por circunstâncias econômicas associadas a diferenciais domésticos de preços relativos.

Como conseqüência, registrava-se, no final do século passado e nas primeiras décadas do atual, uma relativa dispersão de atividades industriais no País. Indústrias como as de fiação e tecelagem, de calçados, de madeira e móveis, de cerâmica e materiais de construção; de processamento de alimentos, de couros e peles, de sabões e velas, de processamento de metais, de produtos farmacêuticos e medicinais, de bebidas e de certos ramos da química mais tradicional, encontravam-se espalhadas em diversas partes do País, de sorte que vários estados brasileiros, localizados em diferentes regiões, emergiam na entrada do século XX como importantes centros regionais de produção manufatureira.

\section{CONCENTRAÇÃO E DISPERSÃO DA INDÚSTRIA NO BRASIL: O CENSO DE 1907}

Evidência da distribuição espacial da indústria, no início do século, é apresentada nas tabelas 1,2 e 3 , confeccionadas a partir das informaçōes levantadas pelo Centro Industrial do Brasil-CIB, em 1907, quando o primeiro censo manufatureiro foi realizado no País.

A Tabela 1 inclui informações sobre população para o ano censitário de 1900 , de modo a permitir comparações entre a distribuição da produção manufatureira com a da população, já que pode ser enganoso discutir dados econômicos sem uma base de referência demográfica. $A$ referida tabela também inclui a computação da produção fabril per capita por macrorregião e por estados selecionados. 
TABELA 1

BRASIL: POPULAÇÃO, PRODUÇÃO INDUSTRIAL TOTAL E
PER CAPITA POR REGIÃO E ESTADOS SELECIONADOS
(1907)

\begin{tabular}{|c|c|c|c|c|c|c|c|}
\hline \multirow{2}{*}{ REGIĀO/Estado } & \multicolumn{2}{|c|}{$\begin{array}{c}\text { População } \\
\text { em } \\
31 / 12 / 1900\end{array}$} & \multicolumn{2}{|c|}{$\begin{array}{c}\text { Estabelecimen- } \\
\text { tos Pesquisa- } \\
\text { dos }\end{array}$} & \multicolumn{2}{|c|}{$\begin{array}{c}\text { Valor da } \\
\text { Produção } \\
\text { Manufatureira }\end{array}$} & \multirow{2}{*}{$\begin{array}{c}\begin{array}{c}\text { Produção } \\
\text { Manufatureira } \\
\text { Per Capita }\end{array} \\
1.000 \text { réis }\end{array}$} \\
\hline & 1.000 & $\%$ & $\mathrm{~N}^{\circ}$ & $\begin{array}{l}\text { Número } \\
\text { de } \\
\text { Operários }\end{array}$ & $\begin{array}{l}1.000 \\
\text { contos } \\
\text { de réis }\end{array}$ & $\%$ & \\
\hline NORTE & 695 & 4,0 & 146 & 3,707 & 32 & 4,3 & 46 \\
\hline NORDESTE & 6.750 & 38,7 & 440 & 38,438 & 124 & 16,7 & 18 \\
\hline $\begin{array}{l}\text { Pernambuco } \\
\text { Bahia }\end{array}$ & $\begin{array}{l}1,178 \\
2,118\end{array}$ & $\begin{array}{r}6,8 \\
12,2\end{array}$ & $\begin{array}{r}118 \\
78\end{array}$ & $\begin{array}{r}12,042 \\
9,964\end{array}$ & $\begin{array}{l}55 \\
25\end{array}$ & $\begin{array}{l}7,4 \\
3,4\end{array}$ & $\begin{array}{l}47 \\
12\end{array}$ \\
\hline SUDESTE & 7,824 & 44,9 & 1,738 & 82,706 & 432 & 58,2 & 55 \\
\hline $\begin{array}{l}\text { R.de Janeiro } \\
\text { São Paulo } \\
\text { Minas Gerais }\end{array}$ & $\begin{array}{l}1.737 \\
2,282 \\
3,595\end{array}$ & $\begin{array}{l}10,0 \\
13,1 \\
20,6\end{array}$ & $\begin{array}{l}877 \\
326 \\
531\end{array}$ & $\begin{array}{r}48,875 \\
24,186 \\
9,555\end{array}$ & $\begin{array}{r}280 \\
118 \\
33\end{array}$ & $\begin{array}{r}37,8 \\
15,9 \\
4,4\end{array}$ & $\begin{array}{r}161 \\
52 \\
9\end{array}$ \\
\hline SUL & 1,796 & 10,3 & 784 & 22,252 & 147 & 19,8 & 81 \\
\hline R.G.do Sul & 1,149 & 6,6 & 314 & 15,426 & 100 & 13,5 & 87 \\
\hline CENTRO-OESTE & 373 & 2,1 & 150 & 4,738 & 7 & 0,9 & 19 \\
\hline BRASIL & 17,438 & 100,0 & 3,258 & 151,841 & 742 & 100,0 & 43 \\
\hline
\end{tabular}

FONTE: Produçáo Industrial: Centro Industrial do Brasil, O BRASIL, Suas Ríjuezas Naturaes, Suas Indústrias, Vol.III, Rio de Janeiro, 1909, (IBGE, Edição Fac Simile, 1986),

População: IBGE, Sinopse Estatística do Brasil, Rio de Janeiro, 1981.

Mesmo considerando-se as grandes imperfeições do Censo de 1907 - censo, como é sabido, realizado por uma instituição privada, a pedido do governo brasileiro - as três tabelas apresentadas a seguir evidenciam uma significativa dispersão da produção industrial pelo terri- 
tório nacional na entrada do século atual, dispersão que é especialmente percebida quando são feitas comparações cruzadas entre distribuição espacial da produção e da populaçāo, como será visto mais adiante.

Os dados da Tabela 1 revelam que, embora a produção fabril já estivesse largamente concentrada no Sudeste (esta região respondendo por cerca de 58 por cento do total da produção industrial, segundo o Censo do $\mathrm{CIB}$ ) e, especialmente, no Estado do Rio de Janeiro que, sozinho, aparecia com quase $2 / 3$ de toda a produção regional - 0 Sul respondia por cerca de $1 / 5$ da produção manufatureira nacional, e o Nordeste por quase 17 por cento. No que diz respeito à distribuição do emprego fabril, os dados revelavam uma concentração um pouco menor. o Nordeste aparecendo com $1 / 4$ do emprego industrial total, o Sul com um pouco menos de 15 por cento e o Sudeste com pouco mais de 54 por cento.

Em nivel estadual, a despeito da grande preponderância do Rio de Janeiro, que sozinho respondia por $37,8 \%$ do valor da produção industrial do País, os Estados do Rio Grande do Sul, com uma participação de $13,5 \%$. São Paulo, com $15,9 \%$ e Pernambuco, com $7,4 \%$, apareciam como centros industriais importantes. Mas outros estados também já estavam engajados em significativa atividade fabril para a época - o Maranhão, a Paraíba e a Bahia, no Nordeste; o Pará, no Norte; Santa Catarina, no Sul, e Minas Gerais, no Sudeste, aparecendo, no Censo de 1907, como centros regionais ou sub-regionais de relativa expressão.

Deve ser acrescido, nesse contexto, que os editores do censo de 1907 admitiam uma subestimação do valor da produção industrial da ordem de $1 / 3$, ou mais. Além do mais, os mesmos editores chamavam a atenção para as enormes dificuldades de obtenção de informações detalhadas até mesmo no antigo Distrito Federal (onde ficava situada a sede do Centro Industrial do Brasil), e esclareciam que a cobertura do levantamento era tão mais precária quanto mais distantes estivessem as indústrias dos estados do Rio e de São Paulo (CIB, 1986, vol.III, pp.256-273). Exemplos de subestimação foram fornecidos pelos editores para uma série de casos, ênfase especial sendo dada às atividades industriais da região Nordeste, particularmente, embora não exclusivamente, no que diz respeito à produção de açúcar, álcool e aguardente. Como a indústria açucareira era o segundo maior ramo industrial brasileiro na época (o primeiro era o têxtil), e como a produção açucareira e de derivados"da cana se encontrava fortemente concentrada no Nordeste, a participação dessa região nos levantamentos do Censo Industrial 
de 1907 estava, sem qualquer sombra de dúvida, grandemente subestimada 1 .

Todavia, mesmo considerando-se que os estados situados fora da região Sudeste estavam sub-representados no censo de 1907, não há qualquer dúvida de que a produção industrial já estava bastante concentrada no Sudeste, e de que, portanto, a industrialização já havia avançado muito mais no Rio de Janeiro, especialmente, e, em menor escala, em São Paulo. Essa constatação não se contrapõe, entretanto, à sugestão acima levantada, da existência de uma significativa dispersão industrial no País, como será mostrado a seguir.

A Tabela 2, construída com dados mais detalhados do censo de 1907, fornece inequívoca evidência do grau de dispersão fabril e da relativa diversificação do parque industrial brasileiro, no início do século. A última coluna dessa tabela, que apresenta informaçōes sobre o número de ramos industriais nos quais o censo de 1907 desagregou a produção manufatureira, claramente suporta 0 argumento da dispersão. $O$ estado do Rio de Janeiro, que apresentava, de longe, a mais diversificada estrutura industrial no Pais, registrava a presença de estabelecimentos fabris em 85 de um total de 97 ramos listados pelo censo. Mas o estado do Rio Grande do Sul era o segundo da lista, comparecendo com a presença de produção industrial em 51 ramos, uma cifra maior do que a de São Paulo, que aparecia com 50 ramos. Minas Gerais registrava a presença de 35 ramos, Pernambuco de 31, e Santa Catarina, de 30 . A Bahia e o Pará compareciam com 26 e 22 diferentes ramos industriais, respectivamente.

1. O Censo de 1907 pesquisou apenas a produçáo das usinas, deixando de lado a produçăo das centenas ou milhares de pequenas e médias fábricas, chamadas de engenhos. Assim, como existiam, no inicio do século, engenhos fabricando açúcar e outros derivados da cana em quase todos os estados brasileiros, o valor da produção deste produto foi grandemente subestimado em escala nacional. Os editores do censo, contudo, deixaram claro que à subestimação referida era particularmente aguda nos estados do Nordeste, região que concentrava o maior número de pequenas unidades fabris. Os editores mostravam, por exemplo, que enquanto nos dois maiores produtores de açúcar localizados fora do Nordeste, a saber, os estados do Rio e de São Paulo, havia 80 e 60 engenhos, respectivamente, cuja produçăo năo havia sido computada, em Pernambuco havia 1.500 engenhos em atividade, e no Rio Grande do Norte 200 -- para tomar apenas esses casos. Para ressaltar o significado da su: bestimação da produção nordestina, os editores chamavam a atenção para o fato de que a produçáo pemambucana de seus engenhos (de açúcar, álcool e aguardente) equivalia a 28.310 contos, uma cifra que chegava a exceder à produção de todas as usinas do Estado, cujo valor era estimado em 27.918 contos. No que diz respeito ao Rio Grande do Norte, enquanto as quatro usinas consideradas no censo produziam um valor estimado de 700 contos, a produçăo dos seus 200 engenhos incrementaria o total computado em 4.600 contos (cf. ClB, op.cit, p.259). 
Informações desagregadas sobre a distribuição espacial da indústria têxtil, que aparecia, de longe, como o mais importante ramo fabril no censo de 1907, fornece evidência talvez ainda mais relevante sobre a dispersão industrial no Brasil.

\section{TABELA 2}

\section{BRASIL: GRAU DE DISPERSÃO E DIVERSIFICAÇÃO ESPACIAL DA INDÚSTRIA (1907)}

\begin{tabular}{llccc}
\hline ESTADOS & REGIÃO & $\begin{array}{c}\text { Número de } \\
\text { Estabel.Industr. } \\
\text { Pesquisados }\end{array}$ & $\begin{array}{c}\text { Número de } \\
\text { Empregados }\end{array}$ & $\begin{array}{c}\text { Número de } \\
\text { "Ramos" } \\
\text { Industr.Existentes } \\
\text { (de um total de 97) }\end{array}$ \\
\hline Rio de Janeiro & Sudeste & 877 & 48,875 & 85 \\
R.G. do Sul & Sul & 314 & 15,426 & 51 \\
São Paulo & Sudeste & 326 & 24,186 & 50 \\
Minas Gerais & Sudeste & 531 & 9,555 & 35 \\
Pernambuco & Nordeste & 118 & 12,042 & 31 \\
Santa Catarina & Sul & 173 & 2,102 & 30 \\
Bahia & Nordeste & 78 & 9,964 & 26 \\
Pará & Norte & 54 & 2,539 & 22 \\
Goiás & Centro-Oeste & 135 & 868 & 20 \\
\hline
\end{tabular}

FONTE: Centro Industrial do Brasil. O BRASIL. Suas Riquezas Naturaes, Suas Indústrias, Vol.III, Rio de Janeiro, 1909. (IBGE, Edição Fac Simile, 1986).

Como no caso da maioria dos outros ramos, a indústria têxtil se apresentava fortemente concentrada no Sudeste. De acordo com os dados levantados pelo $\mathrm{CIB}$, essa regiâo detinha $59 \%$ dos estabelecimentos, $61,5 \%$ do número de empregados e pouco menos de $73 \%$ do valor total da produção nacional de têxteis. Mas restringir-se a esses grandes agregados pode prejudicar seriamente uma análise mais profunda do verdadeiro grau de concentração industrial no Pais, na entrada do século atual. Isto porque se, de um lado, há claras indicações de forte subestimação da produção têxtil em outras regiões, como será sugerido a seguir, por outro lado, os dados agregados escondem muitos aspectos 
desta indústria, que têm fundamental importância quando analisados pela perspectiva espacial.

A Tabela 3, também confeccionada com dados desagregados do censo de 1907, apresenta uma seleção dos maiores estabelecimentos têxteis pesquisados no inquérito do $\mathrm{CIB}$, considerados como tais pelo número de empregados, e distribuídos por região e por estados da federação. Esta tabela, que mostra a distribuição espacial dos estabelecimentos têxteis com mais de 500 empregados, revela que, dos 16 entre os 20 estados onde a produçáa têxtil foi pesquisada pelo censo, em nada menos do que em dez foi registrada a presença de grandes plantas, empregando mais de 500 trabalhadores. Do total das 29 fábricas com. 500 ou mais empregados, 16 se encontravam localizadas no Sudeste: 11, apenas no Rio de Janeiro, quatro em São Paulo e uma em Minas Gerais. No Sul, foi encontrada apenas uma, localizada no estado do Rio Grande do Sul. No Nordeste, por sua vez, 12 fábricas empregando mais de 500 trabalhadores foram encontradas, entre as quais quatro com mais de mil empregados. Nesta última região, não deixa de ser curioso assinalar o fato de como essas grandes fábricas estavam dispersas, já que em seis dos nove estados do Nordeste, o censo encontrou estabelecimentos têxteis empregando mais de 500 trabalhadores: três em Pernambuco, igual número em Alagoas, dois na Bahia (ver, porém, nota de rodapé da Tabela 3), e igual número no Maranhão, um na Paraiba e outro em Sergipe. Os outros três estados da região, embora não tivessem estabelecimentos na faixa dos 500 empregados, segundo o levantamento do $\mathrm{CIB}$, registravam, porém, a existência de fábricas relativamente grandes para a época: o Ceará tinha dois estabelecimentos com mais de 200 trabalhadores (sendo um com 310), o Rio Grande do Norte tinha um com 320 e o Piauí outro com 290 empregados. 


\section{TABELA 3}

\section{BRASIL: DISTRIBUIÇÃO ESPACIAL DOS ESTABELECIMENTOS TÊXTEIS COM MAIS DE 500 EMPREGADOS}

(1907)

\begin{tabular}{lcc}
\hline REGIÃO/Estado & $\begin{array}{c}\text { Número de } \\
\text { Estabelecimentos } \\
\text { com 500 ou mais } \\
\text { empregados }\end{array}$ & $\begin{array}{c}\text { Número de } \\
\text { Estabelecimentos } \\
\text { com mais de 1.000 } \\
\text { empregados }\end{array}$ \\
\hline NORTE & - & - \\
NORDESTE & 12 & 4 \\
Maranhão & 2 & - \\
Paraiba & 1 & - \\
Pernambuco & 3 & $2^{1}$ \\
Alagoas & 3 & 1 \\
Bahia ${ }^{2}$ & 2 & 1 \\
Sergipe & 1 & - \\
SUDESTE & 16 & 7 \\
Rio de Janeiro & 11 & 6 \\
Såo Paulo & 4 & $1^{3}$ \\
Minas Gerais & 1 & - \\
SUL & 1 & - \\
R.G. do Sul & 1 & - \\
CENTRO-OESTE & - & 11 \\
BRASIL & 29 & - \\
\hline
\end{tabular}

FONTE: Centro Industrial do Brasil, O BRASIL, Suas Riquezas Naturaes, Suas Indústrias, VOL.III, Rio de Janeiro, 1909, (IBGE, Edição Fac Simile, 1986).

(1) Inclusive um estabelecimento com 990 empregados. (2) A Bahia tinha outra empresa têxtil com 1.170 empregados, que foi exclulda da tabela, por esta compreender mais de um estabelecimento. É provável, no entanto, que um deles tivesse mais de 500 empregados. (3) O maior e único estabelecimento têxtil de Sáo Paulo com mais de mil empregados era uma fábrica de processamento de juta, com 1.500 operários. (4) $O$ Censo do CIB não pesquisou nenhuma fábrica têxtil nas regióes Norte e Centro-Oeste. Contudo, é muito pouco provável que não existissem atividades têxteis em alguns estados dessas regiōes, particularmente na cidade de Belém do Pará. 
Vale ressaltar, ainda, que o Sudeste, que detinna u maior número dos estabelecimentos com 500 ou mais empregados (16, em contronto com os 12 do Nordeste, como já visto) acusava a presença de sete fábricas têxteis com mais de mil trabalhadores, das quais seis se localizavam no Rio de Janeiro e apenas uma em São Paulo - esta última, na verdade, uma fábrica de processamento de juta, com 1.500 empregados, provavelmente dedicando-se à produção de sacaria para café. Mas - Nordeste também abrigava fábricas com mais de mil operários: quatro, no total, sendo duas em Pernambuco, uma em Alagoas e outra na Bahia.

Considerando que é razoável supor que significativas diferenças tecnológicas não constituiam um elemento diferenciador importante entre os grandes estabelecimentos têxteis na época do censo de 1907, parece ficar claro a existência de uma exṕressiva dispersão industrial no país, no que diz respeito ao principal ramo manufatureiro, ou seja, o têxtil.

Voltando à questão da subestimação da produção industrial, o ponto abaixo discutido tem grande relevância. Embora o Centro Industrial do Brasil tivesse a intenção de levantar todo o universo dos estabelecimentos fabris no País, o censo, como os seus próprios editores reconheceram, deixou de fora uma significativa proporção de fábricas existentes - especialmente, como já acima sugerido, nos estados mais distantes do Rio de Janeiro e São Paulo. Por conta da carência de recursos, seja de ordem financeira ou técnica, e em razão também de várias outras dificuldades encontradas pelos aplicadores do censo (cf. as notas introdutórias dos editores), há claras indicações de que a cobertura da produção fabril variou significativamente entre as regiões. Evidências inquestionáveis de subestimação são encontradas quando examinadas as tabelas desagregadas do censo.

Tomando-se alguns exemplos relativos à indústria têxtil, observase que, enquanto nos estados de Alagoas e Pernambuco, o menor estabelecimento pesquisado tinha, respectivamente, 180 e 120 empregados e a menor de todas as fábricas têxteis do Nordeste, empregava 45 trabalhadores, as tabelas do censo referentes ao Rio de Janeiro incluiam unidades fabris com 16 empregados, as de Minas Gerais com seis, e, no caso de Sã̀o Paulo, até mesmo estabelecimentos com apenas quatro trabalhadores foram pesquisados. Muito estranho, além do mais, foram os casos de três outros estados do Nordeste: a Paraiba, o Rio Grande do Norte e o Piauli, nos quais apenas uma única fábrica em 
cada um deles foi "encontrada", mas nas quais o número de empregados era, respectivamente, de 561, 320 e 289.

Considerando que, além do Rio de Janeiro, de São Paulo e de Minas Gerais - no Sudeste - estados de outras regióes também tiveram incluidas em seus levantamentos unidades fabris de tamanho muito menor (por exemplo: no Rio Grande do Sul, o menor estabelecimento têxtil pesquisado tinha 28 empregados; em Santa Catarina e no Paraná, quatro e três empregados, respectivamente), é muito provável que o censo de 1907 tenha fortemente subestimado a participaçāo da indústria têxtil do Nordeste, a não ser que se faça a inviável suposição de que a produção de manufaturas têxteis se realizava, nesta região, aponas em estabelecimentos relativamente grandes - um fato que caracterizaria o Nordeste como revelando um padrão peculiar de produção, o qual, sem nenhuma razão aparente, contrastaria agudamente com o de todas as outras regiōes brasileiras.

A despeito, porém, de muitas imperfeições, o censo de 1907 constitui uma fonte valiosissima de informaçōes, por ser capaz de fornecer um ótimo retrato do estado geral do desenvolvimento da indústria manufatureira brasileira, no inicio deste século. Um retorno mais uma vez à Tabela 1, que contém dados sobre a distribuição espacial da população e da produção industrial, permite extrair do censo do CIB muitas outras informaçōes iluminadoras. Com efeito, uma comparação da distribuição da população com o valor da produção industrial - tomando as cinco grandes regiões em que o Brasil é hoje dividido pelas autoridades goográficas - revela, por exemplo, que o Nordeste era a região claramente subindustrializada, enquanto o Sul aparecia como a região claramente superindustrializada da nação, se as razões entre população e valor da produção industrial são tomadas como base de referência. De fato, enquanto a participação demográfica do Nordeste era da ordem de $39 \%$ do total nacional, e sua contribuição ao valor global da produção manufatureira era muito menos de metade desta cifra (16,7 por cento), o Sul revelava situação exatamente oposta, sua participação na produção industrial do País de $19,8 \%$, sendo quase o dobro de seu peso demográfi$\infty$, que era de 10,3 por cento.

No que diz respeito ao Sudeste, os percentuais correspondentes à produção manufatureira e à população eram, respectivamente, de 58,2 e $44,9 \%$. Considerando-se o hiato de quase sete anos entre os dados para população (que são os do ano censitário de 1900) e os do censo industrial de 1907, e o fato de que o Sudeste, e muito especialmente o esta- 
do de São Paulo, era, na época, a área de mais intensa expansão demográfica do País (através da imigração estrangeira e, em menor escala, da migração interna), pode-se concluir que a participação da região que concentrava a maior parcela da produção industrial estava apenas em ligeira desproporção ao seu peso demográfico.

Em nivel dos estados, e ainda obedecendo-se ao mesmo critério de comparação entre população e produção fabril, há outros pontos interessantes que ainda valem a pena enfatizar, tanto pela sua relevância para a análise do desenvolvimento regional brasileiro, quanto pelo que se seguirá em outras seçōes deste trabalho. Examinando-se mais uma vez a Tabela 1, e considerando-se para análise, aqui, apenas os estados à época mais importantes, observa-se que Minas Gerais, no Sudeste, e a Bahia, no Nordeste, eram claramente os estados subindustrializados do Brasil, posto que suas participações eram, respectivamente, de 20,6 e 12,2 por cento, com respeito à população, e de 4,4 e 3,4 por cento, respectivamente, em relação à produção manufatureira. Em contraste, 0 Rio de Janeiro, no Sudeste, e o Rio Grande do Sul, no Sul, eram, por seu turno, inequivocamente os estados superindustrializados: o Rio contribuia com $37,8 \%$ de toda a produção industrial nacional, enquanto detinha apenas $10 \%$ da população brasileira, os percentuais correspondentes para o Rio Grande do Sul sendo de 13,5 e 6,6 por cento.

Os outros dois importantes estados, o de Pernambuco, no Nordeste, e o de São Paulo, no Sudeste, tinham, de acordo com os dados dos dois censos mencionados, uma razão equilibrada entre população e produção industrial. Nesse contexto, merece especial consideração o caso de São Paulo, estado que haveria de se tornar, poucas décadas depois, de longe, o maior centro manufatureiro do Brasil. Analisando-se a posição desse estado à luz das razões acima referidas, verifica-se que, para uma participação demográfica de 13,1 por cento do total nacional, São Paulo contribuia com 15,9 por cento do valor da produção manufatureira levantada pelo censo de 1907. Considerando-se o fato de que, no hiato dos 7 anos entre o censo demográfico e o inquérito industrial, o peso populacional de São Paulo deve ter aumentado pelo menos um ou dois pontos percentuais, conclui-se que a posição industrial desse estado no agregado nacional não estava em desproporção ao seu peso demográfico. E é legítimo concluir; também, que de acordo com os dados frios do censo de 1907 , não havia nenhuma indicação clara que sinalizasse para a enorme concentração das atividades industriais nesse estado, que o País veio a testemunhar nas poucas décadas seguintes, e 
que é ainda hoje uma característica dominante do desenvolvimento industrial brasileiro até os dias atuais.

Uma outra forma de olhar os mesmos dados por uma perspectiva ligeiramente diferente, é através do exame da distribuição espacial da produção industrial, em uma base per capita. Esses dados estão apresentados na última coluna da Tabela 1, que mostra a produção manufatureira per capita de cada região e de alguns estados selecionados. A Tabela revela que o Nordeste e o Centro-Oeste eram as regiōes menos industrializadas do Brasil, posto que ambas apresentavam uma produção fabril per capita bastante inferior à média nacional. O Norte se situava ligeiramente acima da média e o Sudeste, como um todo, não se posicionava tão bem, em uma base per capita, posto que a produção industrial por habitante desta região era tão somente 28 por cento acima da média nacional. A região Sul, entretanto, destacava-se claramente das demais regiōes brasileiras, revelando elevado grau de industrialização, já que registrava uma produção fabril per capita que era quase o dobro da média do País.

$\mathrm{Em}$ nivel dos estados, as diferenças no grau de industrialização, ainda de acordo com o critério da produção fabril per capita, sāo bastante mais expressivas. No Nordeste, o estado de Pernambuco, cuja produção industrial foi claramente subestimada pelo censo de 1907 (tal como sucedeu com todas as outras unidades federadas mais distantes do Rio e de São Paulo, como já sugerido neste trabalho), gozava de uma invejável posição na região, sua produção industrial por habitante excedendo inclusive a média nacional em cerca de 10 por cento. Por outro lado, a Bahia (que viria a se tornar, em data mais recente, o estado de base industrial mais desenvolvido do Nordeste), se situava num "ranking" extremamente pobre, com uma produção fabril per capita de apenas 28 por cento da média nacional, superando somente Minas Gerais, que registrava o pior desempenho dentre todos os estados mais importantes do País. O Rio Grande do Sul, por seu turno, destacava-se como o segundo entre os importantes estados brasileiros, com uma produção per capita que excedia em mais do dobro a média nacional, sendo apenas superado pelo Rio de Janeiro.

Atenção especial deve ser dada aos estados do Rio de Janeiro e de Minas Gerais, ambos ocupando uma posição bastante singular. Com uma produção industrial per capita quatro vezes maior que a média nacional, e quase três vezes maior que a da própria região Sudeste, o Rio exibia, no inicio dos anos 1900, de longe o mais elevado grau de indus- 
trialização. O que veio a acontecer com esse estado nas décadas seguintes, que registram, como será visto adiante, um persistente declínio da sua importância industrial, constitui um caso à parte para reflexão. Em situação exatamente oposta, encontrava-se o estado de Minas Gerais, que se posicionava como o menos industrializado de todos os grandes estados brasileiros. Esta singularidade apresentada por Minas Gerais também merece particular atenção, em vista de este estado, no período mais moderno da nossa industrialização, ter conseguido reverter inteiramente sua posição de inferioridade no contexto nacional, a ponto de haver se tornado, nos anos 80 , o segundo maior centro manufatureiro do País. Um possivel caso especial de subestimação pode ser levantado para essa unidade federada, no que diz respeito ao inquérito industrial de 1907. Mas o tato de o número de estabelecimentos fabris pesquisados pelo censo, em Minas, ter sido muito grande (531 unidades), secundado apenas pelo do Rio de Janeiro (877 estabelecimentos) e, acima de tudo, o fato de esse estado também ter se posicionado muito mal nos censos industriais que se seguiram, como será apreciado adiante, parece não deixar dúvidas acerca da posição que Minas efetivamente ocupava no cenário industrial brasileiro, no inicio do século.

$O$ caso de São Paulo talvez seja o mais interessante. $O$ estado que viria a contribuir, já nos anos 50 , com mais da metade de toda a produção manufatureira do País, tinha, ao iniciar-se o século, uma produção industrial per capita não significativamente maior que a média nacional (não mais, de fato, do que $20 \%$ dessa média), produção per capita que era, ademais, menos que $10 \%$ maior do que a de Pernambu$\infty$ e equivalente, ainda, a tão somente $59,8 \%$ da cifra correspondente ao estado do Rio Grande do Sul. Em vista do exposto, e em confirmação à assertiva feita acima sobre a posição ocupada por esse estado, era dificilmente de se esperar, pela simples observação dos dados do censo de 1907, que São Paulo haveria de se tornar, apenas alguns décadas depois, o palco das grandes transformaçōes do cenário industrial brasileiro e, conseqüentemente, que passasse a registrar, de longe, os maiores avanços no processo da industrialização.

\section{INDÚSTRIA, INTEGRAÇÃO REGIONAL E O MERCADO INTERNO}

Antes de se passar à análise de como evoluiu a concentração espacial da produção manufatureira, um comentário final é pertinente, a 
respeito do real significado da indústria no Brasil, no início do século.

Os editores originais do censo de 1907 manifestaram a opinião, com um forte sentimento de patriotismo, de que o setor industrial brasileiro já era uma "grande força" e que constitula a indústria uma muito expresssiva "componente das riquezas nacionais, da qual a nação não possula ainda a menor idéia" (ClB, op.cit., Vol.III, p.273).

De fato, é inegável que o Brasil já havia dado, no iniciar do século $X X$, largos passos no caminho da industrialização. Algumas comparações, porém, com outras variáveis, podem fornecer um quadro mais acurado da realidade brasileira e situar os avanços do nosso processo de industrialização numa perspectiva mais correta.

Como pode ser visto na Tabela 1, o valor total da produção fabril levantada pelo CIB em 1907 foi da ordem de 742 mil contos - uma cifra equivalente a cerca de 46,7 milhões de Libras Esterlinas, ao câmbio do ano (observe-se que o censo trabalhou com o conceito de valor da produção industrial e não valor da transformação, com o qual os censos mais recentes trabalham). Por outro lado, o valor total das exportaçōes, no ano de 1907, foi de 861 mil contos (excedendo, portanto, o valor total da produção manufatureira), 78 por cento do qual representados por apenas dois produtos: café (com 52,7 por cento) e borracha natural (com $25,3 \%)$. As exportaçóes restantes eram constituidas de pequenas quantidades de cacau, fumo, algodão em bruto e açúcar, e despreziveis quantidades de um conjunto de outras matérias-primas.

O Brasil era, assim, altamente dependente da exportação de uns poucos bens primários e, portanto, de uma produção que se realizava lquase que exclusivamente nas suas plantations.

Contudo, para que a comparação entre os dados sobre produção industrial e exportações não dê a impressão equivocada de que a indústria se posicionava mal, no conjunto da economia nacional, devido à importância do nosso setor de exportações, deve ser logo esclarecido que este não era o caso, pois o Brasil dificilmente poderia ser considerado uma grande nação exportadora. Em verdade, tanto numa base per capita quanto em termos absolutos, o tamanho do setor externo era muito modesto no Brasil. E disso já tinham perfeita consciência os editores do conso que, incidentalmente, comentavam, com um sentimento de lamentação, que a vizinha Argentina, com apenas 1/4 da população brasileira, "exportava (no ano do censo) muito mais que o nosso país" (ClB, op.cit., p.155). O Brasil também ficava bastante atrás, em termos per capita (e muito mais ainda em termos absolutos), em relação à Austrá- 
lia, ao Canadá e ao Estados Unidos ${ }^{2}$.

Em síntese, é perfeitamente legítimo concluir, considerando-se o restante da economia brasileira, que o Brasil era, na entrada do Século $X X$, não muito mais do que as suas "export plantations", acrescidas de seus grandes latifúndios pecuários. E que, portanto, a produção para o mercado interno era ainda extremamente atrasada, seja no setor industrial, seja no agrícola.

Nesse contexto, uma outra comparação internacional pode ser muito instrutiva. Os historiadores norte-americanos estimaram que, já por volta do ano de 1847, o valor total da produção doméstica nos Estados Unidos excedia aos 3 bilhões de dólares correntes, dos quais apenas 150 milhões eram exportados para o exterior, deixando, portanto, 2.850 milhōes para serem consumidos no mercado interno (Taylor, 1968, p.207). Além do mais, no ano de 1860, quando as exportaçöes americanas alcançaram 687 milhões de dólares (as exportações brasileiras, nesse ano, atingiam menos de 1/10 desse total, e, ainda em 1907, alcançavam apenas $1 / 3$ das exportações americanas de 1860), o valor anual do comércio interestadual dos Estados Unidos era estimado em 1,5 bilhão de dólares (Schimidt, 1939, p.818, cf. também North, 1963).

No Brasil, todavia, o comércio interestadual era extremamente reduzido. Embora, em 1907, o país já possuísse uma população superior aos 20 milhốes de habitantes, o intercâmbio entre os estados e as regiốes brasileiras não envolvia mais do que uma pequena corrente de comércio, essencialmente constituída de bens de baixo valor - 0 algodão em plumas, o açúcar, o canão, o charque, o feijão, o sal marinho e a farinha de mandioca, sendo os produtos mais importantes da pauta do nosso comércio interior - e pequenas quantidades de uns poucos outros bens de maior valor.

Com efeito, segundo dados levantados sobre o comércio interno para as décadas de 40 e 60, o comércio inter-regional brasileiro somente excedeu ao comércio das regiōes com o exterior, na década de 1950,

2. Chame-se a atençáo para os seguintes pontos: a) no ano de 1907, as receitas com exportaçóes foram as mais altas jấ alcançadas pelo Brasil até entâo; b) o valor das exportaçరos cresceu' a taxas bastante elevadas durante o meio século anterior ao censo, registrando uma expansáo de mais de nove vezes, quando comparado ao nivel das exportaçóes da década de 1842- 1851 - um crescimento, portanto, de mais de $800 \%$ em cinco décadas; $\theta$ c) o Brasil expandiu o seu comércio exterior, no mesmo perfodo, gozando de termos intemacionais de tro. ca bastante favoráveis. Fonte dos dados: valor das exportaçóes, em FIBGE, AEB de 1939-40; Termos de troca para o Brasil no periodo 1850-1907 exportaçסes per capita do Brasil e dos Estados Unidos, em Leff (1982), vol.I, pp.80-82; Exportaçóes da Argentina, Austrália e Canadá, em Dias Alejandro (1985), Tella, (1985), Fogarty, (1985), e Solberg, (1985). 
ou seja, no periodo moderno da história econômica do pais (cf. Galvão, 1988 e 1990) e, portanto, pelo menos um século depois que os Estados Unidos já estavam definitivamente substituindo a dependência dos mercados externos pela dependência do mercado interno, como sua principal fonte de crescimento econômico ${ }^{3}$.

A inexistência de um mercado nacional integrado e a própria pobreza absoluta do mercado interno constituiam, na entrada do século $\mathrm{XX}$, sèm sombra de dúvida, o maior obstáculo ao desenvolvimento da indústria brasileira, muito mais que quaisquer outras razōes, não raro enfatizadas na literatura, como a falta de proteção alfandegária, ou a ausência de uma política de industrialização coerente ou, ainda, os atropelos da conjuntura internacional.

\section{EVOLUÇÃO DA CONCENTRAÇÃO ESPACIAL DA INDÚSTRIA: 1907-1980}

As duas subseções seguintes descrevem a evolução da concentração espacial da indústria, utilizando como fonte de informações dados dos censos da Fundação IBGE.

Como será visto adiante, mudanças notáveis ocorreram na economia brasileira, no que diz respeito à distribuição espacial da produção manufatureira, tanto do ponto de vista das macrorregiões, quanto em nivel das unidades federadas. Assim como a industrialização, neste sẻculo $\mathrm{XX}$, ocorreu promovendo profundas mudanças na posição dos vários estados da federação, o exame dessas mudanças enfatizará não apenas as alterações entre regiōes, mas também as ocorridas dentro de cada região, considerando-se os seus estados economicamente mais importantes.

3. Para uma boa descriçăo da contrastante experiência de desenvolvimento entre o Brasil e os Estados Unidos, esta passagem em Taylor (1968) e muito instrutiva: "(...) por volta de 1860, a organização tanto do comércio exterior quanto do interno [nos USA], havia alcançado um grau de especialização e de integraçáo nacional típico das modernas economias" (p.261), "(...) esta emergente economia nacional de 1860 tinha uma nova orientaçăo. As grandes cidades do Leste não mais olhavam para o mar e náo mais davam atençăo prioritária à navegaçáo de longo curso e ao comércio com o exterior. Agora, as suas relaçס̋es comerciais se centravam crescentemente nas estaçōes ferroviárias, e não mais nos portos marftimos, e as novidades comerciais provenientes de Mobile, Memphis, Louisville, Cleveland e Chicago eram aguardadas com muito mais interesse do que aquelas vindas de Liverpool, Marselha ou Antuérpia" (p.262, traduçăo do autor). 


\subsection{O Periodo 1907-1949}

Durante a primeira metade do presente século, a economia brasileira, como um todo, cresceu a taxas razoavelmente elevadas. A evolução das economias regionais e a de cada estado, contudo, ocorreu a ritmos bem diferenciados, tendo sido particularmente notáveis as diferenças inter-regionais e interestaduais no que diz respeito ao crescimento da produçãa industrial.

A Tabela 4 mostra a distribuição da produção industrial por regiōes e estados selecionados, para o período 1907-1949, com informações extraídas dos censos industriais de 1907, 1919, 1939 e 1949. A Tabela citada revela, para o período em questão, primeiro, que a região Sudeste aumentou sua participação no valor da produção manufatureira nacional de 58,2 para $75,5 \%$; segundo, que esta região melhorou sua posição em todos os quatro censos industriais; e, terceiro, que foi ela, dentre as cinco macrorregiões brasileiras, a única a aumentar, ao longo dos primeiros 50 anos deste século, a sua participação no produto industrial do País. 
TABELA 4

BRASIL: DISTRIBUIÇÃO ESPACIAL DA PRODUÇÃO INDUSTRIAL POR REGIÃO E ESTADOS SELECIONADOS. $(1907,1919,1939$ e 1949)

(Em Percentagem do Valor Bruto da Produção)

\begin{tabular}{lrrrr}
\hline REGIÃO/Estado & 1907 & 1919 & 1939 & 1949 \\
\hline NORTE & 4,3 & 1,3 & 1,1 & 0,7 \\
NORDESTE & 16,7 & 16,1 & 10,1 & 9,2 \\
Pernambuco & 7,4 & 6,8 & 4,6 & 4,0 \\
Bahia & 3,4 & 2,8 & 1,4 & 1,5 \\
SUDESTE & 58,2 & 66,1 & 74,5 & 75,5 \\
R.de Janeiro & 37,8 & 28,2 & 23,9 & 21,1 \\
São Paulo & 15,9 & 31,5 & 43,5 & 46,6 \\
Minas Gerais & 4,4 & 5,6 & 6,7 & 7,1 \\
SUL & 19,8 & 16,1 & 13,7 & 14,0 \\
R.G.do Sul & 13,5 & 11,1 & 9,8 & 8,6 \\
CENTRO-OESTE & 0,9 & 0,4 & 0,6 & 0,7 \\
BRASIL & 100,0 & 100,0 & 100,0 & 100,0 \\
\hline
\end{tabular}

FONTE:

1907 - Centro Industrial do Brasil. O BRASIL. Suas Riquezas Naturaes, Suas Induistrias. Vol.Ill, Rio de Janeiro, 1909, (IBGE, Edição Fac Simile, 1986).

1919 - IBGE, Censo Industrial de 1919. In Recenseamento Geral do Brasil, 1940, Sinopse do Censo Industrial e do Censo dos Serviços, Rio de Janeiro, 1948.

1939 - IBGE, Censo Industrial de 1939, In Recenseamento Geral do Brasil, 1940, Sinopse do Censo Industrial e do Censo dos Serviços, Rio de Janeiro, 1948.

1949 - IBGE, Censo Industrial de 1949, In VI Recenseamento Geral do Brasil, 1950, Vol.III, Tomo I, Rio de Janeiro, 1957.

A análise por censo, por região e por estados selecionados revela algumas situaçōes muito iluminadoras.

No que diz respeito à região Norte, a Tabela 4 mostra que, entre 
1907 e 1919, a participação desta região no total da produção industrial do Pais despencou de $4,3 \%$ para $1,3 \%$, continuando a cair ainda mais nos censos subseqüentes, alcançando 1,1\% em 1939 e tão somente $0,7 \%$ no censo de 1949 . As razões desta enorme deterioração na posição da região Norte são bem conhecidas e se devem ao ocaso da exploração da borracha na Amazônia. O efeito do drástico declínio dos preços da borracha foi catastrófico para os estados amazônicos, e a grande contração das atividades extrativistas na região, a partir da primeira década deste século, está, sem qualquer sombra de dúvida, por trás do seu fraco desempenho nos censos industriais que se seguiram. De fato, a dramática queda nos preços internacionais da borracha, ao reduzir os niveis da renda e da demanda efetiva regional, afetou intensamente as atividades fabris na Amazönia, a ponto de o estado do Amazonas, que no censo do CIB de 1907 aparecia contribuindo com uma produção industrial de 13.962 contos, registrar uma produção de apenas 5.702 contos no censo do IBGE de 1919 - um decréscimo, portanto, em termos nominais (já que as duas cifras são dadas em valores correntes) da ordem de 60 por cento. O desempenho do estado do Amazonas é ainda mais expressivo, ao se verificar que este estado foi o único, dentre todas as 21 unidades da federação na época, a ter sofrido, entre os dois anos censitários em referência, uma queda nominal na sua produção manufatureira.

Com relação à região Nordeste, o censo de 1919 mostra, talvez surpreendentemente, um desprezivel declínio de sua participação na produção fabril nacional: 16,1 por cento em 1919, em comparação com 16,7 por cento em 1907. O Nordeste aparecia, além do mais, como a região que, nas duas primeiras décadas deste século, sofreu o menor declínio relativo de todas as regiōes brasileiras. Se, contudo, um escrutínio rigoroso de ambos os censos mencionados for realizado, a explicação para este fato tornar-se-á bastante transparente. Argumentou-se na seção anterior, que havia uma clara indicação de que a produção manufatureira desta região estava desproporcionalmente subestimada no censo de 1907, em relação às outras regiões brasileiras. O censo de 1919 parece confirmar de forma clara o argumento. Primeiro, porque a cobertura deste último censo foi muito maior, compreendendo 13.569 estabelecimentos industriais em todo o Brasil, em comparação aos 3.258 apenas, do censo de 1907 (uma maior cobertura, a propósito, explica melhor o grande incremento no número de estabelecimentos, do que uma hipotética, porém inviável, "explosão" de crescimento industrial 
no Brasil, no início do século). Em segundo lugar, porque a cobertura dos estabelecimentos industriais no Nordeste foi também muito maior do que a do ano de 1907, passando então a incluir muitas unidades fabris que não haviam sido pesquisadas pelo censo do CIB: 2.572 estabelecimentos, em 1919, em confronto com tão somente 440 em 1907 nenhuma razão aparente justificando, como no caso do País como um todo, tamanha ampliação do número de estabelecimentos no Nordeste, no curto periodo de apenas 12 anos. Finalmente, porque o grau de cobertura dos estabelecimentos pesquisados aumentou muito mais no Nordeste do que em qualquer outra região do Brasil. Evidência clara disso é o fato de que, enquanto o número de estabelecimentos industriais pesquisados pelo censo de 1919 se ampliou em quase seis vezes no Nordeste, a cifra correspondente para o restante do Pais foi de apenas 3,9 vezes.

Essas considerações conduzem às seguintes conclusōes: a) que a indústria brasileira como um todo era menos concentrada, espacialmente, do que o censo de 1907 estaria a indicar, b) que o grau de diversificação e de dispersão espacial da produção manufatureira era maior do que o sugerido pelo censo referido, consistentemente com o argumentado em seção anterior deste trabalho; e c) que a indústria no Nordeste, no início do século $X X$, apresentava uma participação bem maior no total da produção industrial brasileira, do que o sugerido pelo censo de 1907.

O reconhecimento dessas constatações leva a duas implicações necessárias: a) como o censo de 1919 é muito mais perfeito que o do $\mathrm{CIB}$, refletindo, assim, bastante melhor as reais condições da indústria brasileira, do que o censo de 1907, o declínio relativo do Nordeste no contexto da industrialização nacional foi, na verdade, muito maior durante as duas primeiras décadas do século $X X$, do que fica sugerido por comparaçōes não críticas dos dois censos industriais referidos; e b) que a região Nordeste estava colocada, desde o início do século, numa posição muito mais desvantajosa para crescer, quando comparada às outras regiōes do Pais.

A performance do Nordeste, tal como revelada nos censos industriais seguintes, fornece evidência adicional para 0 argumento acima exposto. Ao serem divulgados os dados do terceiro censo industrial, o de 1939, a participação da região no valor bruto da produção manufatureira naciọnal havia caido para 10,1 por cento, em comparação aos 16,1 por cento de 1919 , caindo mais ainda no censo de 1949 , para $9,2 \%$. 
Comparando-se o período completo de 1907 a 1949, e exclundo o caso excepcional do Norte, por razōes já examinadas, conclui-se que o Nordeste se apresentava, claramente, como a região que havia sofrido o maior declínio na sua participação nacional na indústria, dentre todas as regiōes brasileiras. A sua posição relativa teria caído de 45 por cento, em comparação com menos de 1/3 para a região Sul, e aproximadamente 22 por cento para o Centro-Oeste.

A análise da evolução da concentração industrial do ponto de vista das mais importantes unidades da federação, talvez revele resultados ainda mais significativos. No Nordeste, seus dois mais importantes estados, Pernambuco e Bahia, perderam terreno no processo da industrialização brasileira, no período 1907-1949, a um ritmo ainda mais rápido do que ocorreu com a região como um todo. Pernambuco viu sua participação no valor da produção manufatureira nacional cair de 7,4\% em 1907, para $4 \%$ em 1949, e a Bahia perdeu ainda mais, declinando sua participação de 3,4 para 1,5\%, no período correspondente. No Sul, por sua vez, o estado do Rio Grande que, no início do século, detinha uma posição praticamente idêntica à de São Paulo, também sofreu uma grande perda relativa, sua participação declinando de 13,5\% em 1907, para cerca de $8,6 \%$ ao findar a primeira metade do século.

Mais importante de tudo, porém, foram as mudanças nas posiçōes dos estados da região mais desenvolvida e que também se industrializava a ritmo mais veloz. $E$ nesse contexto, não parece haver dúvida de ter sido a extraordinária concentração da produção fabril em São Paulo, o o também extraordinário declínio do estado do Rio de Janeiro, a caracteristica mais significativa do processo do desenvolvimento industrial brasileiro.

Ambos os fenómenos: o dramático declínio industrial do estado do Rio e a notável expansão do parque fabril de São Paulo, devem merecer cuidadosa atenção. Isto porque, enquanto no período 1907-1949, a contribuição do Rio de Janeiro ao valor bruto da produção industrial do País se reduzia a quase metade, passando de $37,8 \%$ para apenas $21,1 \%$, a participação de São Paulo praticamente triplicava, elevando-se de $15,9 \%$ para $46,6 \%$. Além do mais, foi suficiente apenas o curto espaço dos 12 anos entre o censo de 1907 e o de 1919 para São Paulo ultrapassar o Rio de Janeiro, e vir a tornar-se o principal centro manufatureiro da Nação, desbancando, assim, a posição de liderança que o Rio por tanto tempo detivera.

Ainda no Sudeste, Minas Gerais também melhorou significativa- 
mente sua posição, este estado passando de sua modestíssima participação de $4,4 \%$ do produto industrial brasileiro, em 1907 , para $7,1 \%$, em 1949. Com esta mudança, Minas foi capaz de alterar a posição de inferioridade que registrara no início do século, passando a gozar o status de quarto centro manufatureiro do País, atrás apenas de São Paulo, do Rio de Janeiro e do Rio Grande do Sul.

Assim é que, ao findar a primeira metade do século atual, os quatro estados que formavam a região Sudeste já concentravam mais de $3 / 4$ de toda a produção fabril brasileira, sendo que somente a indústria de São Paulo e a do Rio somadas, representavam quase $68 \%$ do total nacional, enquanto esses dois estados detinham $26,6 \%$ da população e tão somente $3,4 \%$ do território da nação.

\subsection{O Periodo 1950-1980}

Na segunda metade do século $X X$, Brasil testemunhou o fortalecimento das principais tendências já registradas na primeira metade, embora alguns novos e importantes traços no nosso processo de industrialização possam ser anotados.

O primeiro aspecto geral a chamar a atenção é que, durante as duas décadas que se seguiram ao Censo Industrial de 1949, aumentou ainda mais a concentração espacial da produção industrial no Pails, 0 Sudeste elevando a sua participação no total da produção fabril brasileira de $75,5 \%$, em 1949, para $77,3 \%$, em 1959 , e para $78,7 \%$ em 1970 (Cf. Tabela 5). 
TABELA 5

\section{BRASIL: DISTRIBUIÇÃO ESPACIAL DA PRODUÇÃO INDUSTRIAL POR REGIĀO E ESTADOS SELECIONADOS.}

$(1959,1970,1975$ e 1980)

(Em Percentagem do Valor Bruto da Produção)

\begin{tabular}{lrrrr}
\hline REGIÄO/Estado & 1959 & 1970 & 1975 & 1980 \\
\hline NORTE & 0,9 & 0,9 & 1,1 & 1,9 \\
NORDESTE & 7,8 & 6,5 & 6,7 & 7,7 \\
Pernambuco & 2,8 & 2,2 & 2,2 & 2,0 \\
Bahia & 1,9 & 1,7 & 2,1 & 3,4 \\
SUDESTE & 77,3 & 78,7 & 76,3 & 73,0 \\
R.de Janeiro & 16,2 & 14,9 & 12,5 & 10,4 \\
São Paulo & 54,8 & 55,6 & 55,5 & 53,5 \\
Minas Gerais & 6,0 & 7,6 & 7,6 & 8,4 \\
SUL & 13,3 & 12,9 & 14,8 & 16,2 \\
R.G.do Sul & 7,2 & 6,7 & 7,3 & 7,2 \\
CENTRO-OESTE & 0,7 & 1,1 & 1,2 & 1,2 \\
BRASIL & 100,0 & 100,0 & 100,0 & 100,0 \\
\hline
\end{tabular}

FONTE:

1959 - IBGE, VII Recenseamento Geral do Brasil, 1960, Censo Industrial de 1959, Rio de Janeiro, 1963.

1970 - IBGE, VII Recenseamento Geral do Brasil, 1970, Censo Industrial de 1970, Rio de Janeiro, 1973.

1975 - IBGE, Censos Económicos, Censo Industrial de 1975, Rio de Janeiro, 1981.

1980 - IBGE, Anuário Estatistico do Brasil, 1962, Rio de Janeiro, 1983.

A tendência de o Rio de Janeiro ver a sua indústria perder terreno no contexto nacional continua a merecer especial registro, posto que o declínio que este estado apresentou na primeira metade do século, continuou a ocorrer inintemuptamente nas décadas seguintes. Com efeito, a participação do estado do Rio caiu de $21,1 \%$ em 1949, para 16,2\% em 1959, para cair de novo para $14,9 \%$ em 1970, e ainda mais em 1975 , para $12,5 \%$, alcançando apenas $10,4 \%$ em 1980 , de acordo com os censos industriais dos anos mencionados. Desta forma, o principal centro 
manufatureiro do País no inicio do século, e que concentrava sozinho quase $40 \%$ de todas as atividades industriais brasileiras, estava reduzido, em 1980, a uma participação que era apenas ligeiramente superior a $1 / 4$ dessa cifra.

O comportamento do estado de Minas Gerais na segunda metade do século é particularmente instrutivo, por oferecer interessantes lições no campo da economia política. Como foi visto na subseção anterior, Minas conseguiu crescer industrialmente mais rápido do que o País até a década dos 40, conforme revelam os censos industriais de 1907 a 1949. Ademais, este estado elevou a sua contribuição ao produto fabril brasileiro em todos os anos censitários realizados na primeira metade do século, passando de uma participação de $4,4 \%$, em 1907 , para $7,1 \%$, em 1949. Todavia, Minas viu a sua economia passar por dificuldades crescentes a partir de então, dificuldades que parecem ter sido particulamente notáveis nas décadas de 50 e 60 . O censo industrial de 1959 consegue captar a interrupção do dinamismo mineiro que teria ocomido nos anos de pós-guerra, ao mostrar a participação do estado caindo dé $7,1 \%$, em 1949, para $6 \%$ em 1959, Minas só voltando a alcançar a cifra mais alta da primeira metade do século, no censo industrial de 1970, ao legistrar uma participação de $7,6 \%$ do prơduto manufatureiro do País.

A reversăo da tendência ao declínio relativo da indústria de Minas, bem como, na verdade, grande parte do sucesso da economia mineira em afirmar-se, em periodo mais recente do nosso desenvolvimento, como o segundo centro manufatureiro do País, devem-se menos a efeitos naturais ou espontâneos de espraiamento do capitalismo brasileiro, do que a circunstâncias políticas especificas, resultantes da rica experiência histórica do desenvolvimento desse estado. Com efeito, as preocupaçōes de Minas com 0 atraso de sua economia são muito antigas e, pelo menos desde o final do século passado, os sucessivos governos de estado tentaram adotar políticas de diversificação econômica (cf. Cammack, 1982) e de industrialização, especialmente a partir dos anos 30 deste século. Durante as décadas de 30,40 e 50, vários diagnósticos da economia mineira denunciavam um quadro alarmante de declínio e quase sempre as causas do empobrecimento do Estado eram associadas a sua proximidade física com os vizinhos estados do Rio e de São Paulo, ou seja, aos efeitos polarizadores exercidos pelas economias mais desenvolvidas desses dois estados (cf. Wirth, 1977). Movidos por uma aguda percepção da condição de dependência de sua economia do Rio e de São Paulo, os mineiros teriam procurado a todo custo reduzir 
tal dependéncia, Minas Gerais talvez constituindo o estado brasileiro que, politicamente, mais se empenhou em desatrelar o dinamismo da sua economia à dos dois estados citados e, também, o que mais tentou criar uma base económica com uma dinâmica própria. Em verdade, $\infty$ mo Minas ficou exposta, bem mais cedo do que qualquer outro estado brasileiro, à concorrência do eixo Rio/São Paulo, esse estado teria desenvolvido uma extrema percepção dos perigos da tutelagem económica, ou seja, dos efeitos de uma espécie de endocolonialismo, o que veio levar, conforme sugere Wirth (op.cit. p.230), a que suas elites políticas, suas associações comerciais e seus representantes industriais, procurassem agir sempre com a idéia de livrar o Estado da sua relação de dependéncia. Dentro desse contexto, o Governo do Estado foi chamado a desempenhar um papel decisivo, de sorte que, mesmo aceitando-se a tese de que Minas não teria sido bem-sucedida em seus esforços no passado, não parece restar dúvida de que o estado mineiro estava bem. preparado ideológica, política e organizacionalmente, para obter o seu quinhão, em periodo mais recente do nosso desenvolvimento. A importância da mobilização política de Minas e do fortalecimento do aparato do Governo do Estado com vistas à promoção de políticas de auto-afirmação, é reconhecida por vários estudos recentes sobre a economia minera (cf. Paiva, 1988, Diniz, 1988 e Brito, 1988). Os frutos dessa mobilização, que também passava pela conquista de uma maior parcela dos investimentos da União e pela reivindicação de uma presença mais expressiva de Minas na política de industrialização do País, traduziramse numa melhoria significativa da posição do estado nos anos 70 , de sorte que Minas, ao alcançar uma participação de $8,4 \%$ da produção industrial brasileira, havia se tornado o terceiro centro manufatureiro da Nação, ao se concluir o levantamento censitário de 1980. E, embora o censo industrial de 1985 ainda não tenha sido divulgado, há claras indicações de que esse estado deve ter alcançado a posição de segundo maior centro fabril do País, ultrapassando o Rio de Janeiro, que ainda mantinha esta posição no ano de 1980.

Um outro aspecto importante a destacar é o da continuação da forte tendência à concentração da indústria em São Paulo. Durante as décadas de 1950 e 1960, esse estado veio a consolidar definitivamente a sua posição de primeiro centro manufatureiro do País, ao saltar de uma participação na produção fabril nacional de $46,6 \%$, em 1949 , para $54,8 \%$, em 1959, aumentando ainda mais essa participação em 1970, para $55,6 \%$. A partir dos anos 70 , contudo, a taxa de crescimento da 
produção industrial de São Paulo parece ter ficado ligeiramente atrás da: do resto do País. Com efeito, se os dois primeiros censos industriais da segunda metade deste século (os de 1959 e 1970) revelaram que a produção fabril brasileira continuou se concentrando no Sudeste e, especialmente, em São Paulo, os dois censos seguintes (os de 1975 e 1980) registraram pela primeira vez, desde 1907, uma tendência à desconcentração geográfica da indústria, tanto o Sudeste como um todo, quanto São Paulo, revelando, na década de 70 , um crescimento de suas indústrias manufatureiras abaixo da média daquelas do resto do País.

Estariam tais dados efetivamente a indicar um processo de desconcentração industrial no Brasil? A primeira vista, a resposta parece claramente afirmativa, posto que no período 1970-1980 todas as re giōes brasileiras aumentaram a sua participação no valor total da produção manufatureira, às expensas do Sudeste mais industrializado.

Curiosamente, todavia, deve ser observado que os ganhos de participação alcançado pelas regiōes brasileiras, em periodo recente, ocorreram em larga medida às expensas do industrialmente decadente Estado do Rio de Janeiro, e muito pouco às expensas do estado mais industrializado do País. Pois enquanto o Sudeste como um todo reduz, no período 1960-1980, em 4,3 pontos percentuais sua participação na produção manufatureira nacional, a perda relativa do Rio foi de 5,8 pontos percentuais, em contraste com tão somente 1,3 ponto percentual no tocante a São Paulo. Na década 1970-80, o Sudeste perdeu 4,7 pontos percentuais e São Paulo 2,1 pontos, sendo que a totalidade da perda relativa deste último estado ocorreu somente entre 1975 e 1980.

Levando-se em conta que a indústria do estado do Rio vem revelando um declínio relativo ininterrupto desde o primeiro censo industrial de 1907 até o último censo disponivel, o que tais dados estariam a sugerir é a enorme dificuldade de se reverter, em nivel regional, padrões historicamente consolidados de alocação de recursos, em economias que alcançam o elevado grau de concentração industrial como o registrado no Brasil.

Ademais, a experiência do desenvolvimento nacional e de suas regiōes no pós-guerra, não autoriza prediçōes definitivas quanto à continuidade de uma tendência à desconcentração industrial, a partir de duas observaçōes censitárias que cobrem uma única década apenas. Como é sabido, a economia brasileira entrou na década dos 70 e continuou durante todo o decênio dos 80 , enfrentando enormes dificuldades para crescer, em decorrência, entre outras razōes; dos "choques do petróleo" 
e das exigências de pagamento do serviço da dívida externa. Durante os últimos 15 anos, a economia nacional como um todo, vem alternando taxas relativamente altas de crescimento, com periodos de reduzida expansão, e mesmo assinalando taxas negativas de crescimento do PIB ocorrência pela primeira vez registrada desde a década dos 40 , quando estatísticas de contas nacionais começaram a ser levantadas sistematicamente no Brasil.

Diante de um quadro recessivo tão prolongado, como o que vem atravessando o País, prediçōes acerca de mudanças estruturais, a exemplo de uma reversão de tendência quanto ao crescimento industrial em nivel espacial, se tornam extremamente arriscadas, se não se dispōe de um período mais longo para observação. Tal acautelamento tem apoio em ampla evidência factual, pois o confronto de taxas de crescimento de estados e regióes com as relativas à economia nacional, tem revelado que, nos periodos recessivos, as regióes mais atrasadas crescem acima da média nacional, ocorrendo o oposto nos períodos de normalidade econômica, ou quando a economia nacional está crescendo rapidamente (cf. BNB, 1978: PIMES/UFPE, 1984).

Assim, desde que a tendência de desconcentração industrial captada pelos censos de 1975 e 1980 é um fenômeno restrito à última década, parece válido colocar a questão de se esta tendência não estaria refletindo, de modo essencial, condiçōes adversas de crescimento do Sudeste, cabendo perguntar, conseqüentemente, se teria ela continuidade após o retorno à normalidade econômica do pais, quando a região mais industrializada retomaria o seu padrão histórico de crescimento.

Os dados dos censos industriais da segunda metade do século ainda permitem a análise de outros aspectos relevantes. No que diz respeito à evolução industrial do Sul, foi esta a região a alcançar, nos dois últimos censos manufatureiros, o maior incremento absoluto de participação no produto fabril brasileiro, os dados sugerindo que os estados sulinos estariam conseguindo reverter uma situação estrutural de dificuldades por que teriam atravessado suas indústrias desde 0 início do século. Com efeito, a Região como um todo adicionou 3,3 pontos percentuais à sua participação na produção industrial brasileira, no periodo de 1970-1980, alcançando uma cifra de 16,2\%, voltando, assim, ao nivel que a região havia registrado no ano censitário de 1919 - o mais alto obtido pelos estados sulinos dentre todos os censos da FIBGE. Esta melhoria na posição da região Sul parece estar, sem dúvida, associada aos esforços de exportação a que se lançou o Pais na segunda me- 
tade dos 60, quando esta região tornou-se uma grande exportadora de grãos (especialmente soja e derivados), de carnes e de produtos manufaturados (especialmente calçados) para o exterior, além de ter fortalecido ainda mais o seu tradicional papel de região "celeiro" do País.

O Norte, por sua vez, foi a região que, depois do Sul, mais incrementou a sua participação na produção fabril nacional, adicionando a esta um ponto percentual durante o período 1959-1980 - embora a contribuição dessa região ao agregado nacional ainda tenha sido insignificante, ou seja, de 1,9\% do total do produto fabril do País. Todavia, este incremento pode ser visto como um grande feito para os estados amazônicos, se isto significar ter a região conseguido interromper, definitivamente, a tendência sistematicamente declinante de sua participação industrial desde 0 início deste século e que teria continuado até pelo menos os anos 50 . As razões para esta talvez inflexão nos padrões do crescimento da região Norte são várias: o aumento significativo de sua população em datas recentes; o fato de a região ser ainda uma área de expansão de fronteira no País; e os efeitos da política de incentivos fiscais, tanto para a indústria quanto para a agricultura, que o Governo Central vem implementando desde os anos 60. Mas, acima de tudo, parece ter sido a criação da Zona Franca de Manaus no final dos 60, a razão principal da melhor performance da região Norte, no período 1960-1980.

A região Centro-Oeste veio em seguida, elevando a sua participação na produção industrial do País em 0.5 ponto percentual, no periodo 1950-1980. Contudo, embora este aumento tenha significado uma quase duplicação de sua participação, o peso do Centro-Oeste era ainda mais insignificante do que o da Região Norte, não ultrapassando 1,2\% do agregado nacional.

O Nordeste é um caso à parte. Com uma população de quase 40 milhōes de habitantes, o que situa a região como a terceira mais poptlosa área em toda a América Latina (após o próprio Brasil e o México), o Nordeste, a despeito de ter presenciado as primeiras iniciativas de industrialização do País (especialmente com respeito às indústrias têxteis), atravessou, durante todo o século $\mathrm{XX}$, um processo profundo de deterioração de sua economia e de aguda perda relativa no contexto da industrialização nacional. Em período recente, a região começou a receber tratamento especial do Governo Central, e um ambicioso programa de industrialização foi implementado a partir de 1960, através dos conhecidos mecanismos de incentivos fiscais à sua agricultura e à indús- 
tria, que trouxeram à região mais de 1.500 novos ou modernizados estabelecimentos industriais. Contudo, assim como a reversão do processo de concentração espacial da indústria, em nivel nacional, tem se mostrado dificil de se materializar, de igual modo difícil tem se mostrado a reversão do longo processo histórico de declínio econômico do Nordeste. Assim é que, tomando-se o período de 1950 a 1980 como um todo, o Nordeste continuou a ver a sua posição industrial se deteriorar, declinando a sua participação de $9,2 \%$ em 1949, para 7,7\% em $1980-$ uma perda, portanto, de 1,5 ponto percentual na sua contribuição ao valor da produção industrial do País. Essa tendência declinante foi particularmente intensa no periodo 1950-1970 - quando, incidentalmente, foi intensificado o processo de integração do Nordeste ao resto do País (cf. Galvâo, 1988 e 1990) - verificando-se uma queda na participação da região de 9,2\%, em 1949, para tão somente 6,5\%, em 1970 - a mais baixa participação do Nordeste dentre todos os censos industriais. Entre 1970 e 1980, porém, esta tendência de declínio é interrompida, a Região melhorando a sua posição no contexto da indústria nacional em 0.2 ponto percentual na primeira metade da década, e ainda mais na outra metade, em 1,0 ponto percentual.

Um último aspecto sobre a melhoria da posição do Nordeste merece aqui consideração, por também oferecer algumas liçōes no campo da economia política. Como visto acima, esta região, como um todo, incrementou a sua participação no produto industrial brasileiro em 1,2 ponto percentual, na década de 70 . Todavia, o estado de Pernambuco, que foi o maior beneficiário da política federal de promoção industrial à região, no que diz respeito à atração de capitais privados, continuou vendo sua participação declinar, a sua contribuição ao valor da produção fabril brasileira caindo de 2,8\% em 1960, para 2,2\% em 1970 e 1975 e para $2 \%$ em 1980. Em exato contraste com Pernambuco e, certarnente, com os demais estados do Nordeste, a Bahia viu a sua participação evoluir de $1,7 \%$ em 1970 , para $2,1 \%$ em 1975 , para alcançar $3,4 \%$ no censo industrial de 1980 . Como é sabido, a Bahia tornou-se, a partir dos anos 70, um locus privilegiado para grandes investimentos do Governo Federal que, sozinho, ou em associação com grandes empresas estrangeiras ou nacionais de capital privado, implantou no referido estado, o maior complexo industrial petroquímico da América Latina. Como resultado, a Bahia que, em 1975, ainda estava atrás de Pernambuco tornouse, em um período de apenas cinco anos, o principal centro manufatureiro do Nordestê, superando de longe Pernambuco e passando a con- 
tribuir com quase $45 \%$ de toda a produção industrial da região. Em suma, a Bahia teria sido responsável, praticamente sozinha, pela melhoria da posição que a região nordestina teria revelado entre os censos industriais de 1970 e 1980. A recente experiência baiana estaria a confimar, assim, que no desenvolvimento brasileiro e, individualmente, de seus estados, a maior ou menor presença do Estado constituiria fator explicativo essencial de diferenciais de desempenho.

\section{CONCLUSÕES}

Estudo recente do BNDES, que discute a possibilidade de uma desconcentração espacial da indústria no Brasil, assinala quatro vantagens principais que poderiam resultar de uma mudança na orientação do desenvolvimento industrial brasileiro.

1) uma integração mais efetiva das regiões periféricas ao processo do desenvolvimento nacional;

2) a garantia da continuidade do crescimento do País, pela agregação de novas áreas e novos consumidores;

3) a superação de gargalos infra-estruturais nas áreas mais industrializadas, decorrentes do excesso da concentração espacial dos investimentos;

4) o aumento do grau de eficiência produtiva do parque industrial brasileiro, em virtude do fato de que a instalação de indústrias em novas áreas, ao invés de sua expansão em áreas velhas, permitiria, de um lado, a montagem de unidades fabris mais modernas e, de outro, a implantação de muitos equipamentos intra-estruturais a custos mais baixos (Cf. BNDES, 1986, pp.24).

O mesmo estudo reconhece, todavia, que a tendência à concentração geográfica da indústria deverá permanecer no Brasil, nas próximas décadas, caso nāo seja profundamente alterada a atual política ou orientação governamental a respeito do curso do nosso desenvolvimento industrial (Idem, p.1).

As preocupaçōes reveladas pelo BNDES no estudo citado são compartilhadas por analistas de países onde a concentração industrial ocorre em escala bem menor do que no Brasil. Na verdade, o problema de uma excessiva concentração geográfica da indústria e o da dificuldade de sua reversão, têm constituido uma questão preocupante nas nações de todo.o mundo (mesmo que nāo prioritária face a outras ques- 
tões nacionais) - sejam países desenvolvidos ou não. Com efeito, muitas nações industrialmente avançadas, como a Grã-Bretanha e a França, chegam até a adotar severos esquemas de penalização para todo investidor privado que insiste em localizar suas atividades industriais nas proximidades das regiōes metropolitanas, como a Grande Londres e a Grande Paris (Cf. Allen \& Maclennan, 1970 e Holland, 1971). A rationale de tais medidas, segundo planejadòres e teóricos régionais, é a existência de acentuadas divergências entre custos privados e sociais. $\mathrm{O}$ argumento básico é o de que os investidores industriais, quando de suas decisões locacionais, "calculam" tão somente uma relação custo/benefício privada de seus investimentos, desconsiderando muitos outros custos que são crescentemente assumidos pelo Estado, nas áreas de grande concentração de indústrias. Assim, ao transferir-se para o Estado a responsabilidade da cobertura de tais custos, passa a nação inteira a pagar o alto ónus que resulta do congestionamento industrial $e$, pior que tudo, passa também o país a ver criado um mecanismo perverso, mas que funciona com extraordinária eficácia, de reforço e perpetuação da tendência à concentração industrial.

Há um outro aspecto importante ainda a considerar: o relacionado com a dimensão territorial do pais que apresenta diferenças inter-regionais acentuadas de desenvolvimento industrial. É possivel argumentar que um alto índice de concentração geográfica da indústria, em nações de pequena dimensão territorial (caso dos países europeus, por exemplo), traz implicaçōes bastante menos significativas, comparativamente a paises de grande extensão territorial, no que diz respeito à utilização de seus potenciais produtivos. Nos países territorialmente menores, as distâncias relativamente mais curtas entre os mercados, as fontes de insumos e os espaços onde se localizam as unidades industriais, facilitam os deslocamentos inter-regionais, tanto da mão-de-obra quanto dos bens produzidos, proporcionando, assim, custos muito menores de transferência e reduzindo, por conseqüência, a possibilidade de que vastos recursos da nação fiquem subutilizados ou que nem sequer sejam utilizados. Nos países que dispóem de um vasto território porém, as implicaçōes de uma concentração espacial excessiva das atividades económicas assume características bem especiais.

Neste sentido, vale mencionar, aqui, o notável contraste entre países como os Estados Unidos e o Brasil. Os Estados Unidos, por uma série de circunstâncias históricas favoráveis, presenciaram desde cedo uma revolução nos seus sistemas de transportes internos - o país tor- 
nando-se todo percorrido, já na segunda metade do século passado, por uma densa malha ferroviária, e por uma extensa rede, tanto natural quanto artificial, de aquavias, sejam lacustres, fluviais ou costeiras. A industrialização nesse pais, ocorrendo de forma geograficamente desconcentrada, contribuiu largamente para consolidar e revigorar os seus sistemas interiores de transporte de longa distância e um processo de convergência de rendas regionais per capita constitui um dos traços mais marcantes da economia americana (Cf. Perloff et alii, 1965).

O Brasil, ao contrário da economia norte-americana, evoluiu como um arquipélago de ilhas humanas - essas "ilhas", ou regiōes, mantendo entre si, escassos elos econômicos, até data relativamente recente. Em virtude da pobreza do mercado interno - seja o da nação como um todo, seja o de cada uma de suas regiōes -, o País foi incapaz de desenvolver sistemas nacionais eficientes de transporte de longa distância, não dispondo, até hoje, de uma verdadeira rede nacional de ferrovias e de um sistema eficiente de cabotagem -- meios de transporte que, para serem economicamente viáveis, exigem grande volume de carga em duas direções - o que ainda é uma realidade não próxima de ser alcançada nos dias atuais. Por sua vez, a industrialização processando-se de forma geograficamente concentrada em exigua parte do território nacional, veio agravar ainda mais esse quadro.

As rodovias, que emergiram na era moderna do nosso desenvolvimento como o único sistema de transporte capaz de interligar efetivamente os vários espaços nacionais, refletem, em larga medida, os atuais padrões da industrialização brasileira. Os sistemas de transporte por caminhão são conhecidos por sua maior flexibilidade técrica e econômica, em contraste com outros modos de transporte, como o ferroviário e a cabotagem. Aqueles, podem ser viáveis e eficientes (do ponto de vista privado, mas não necessariamente do ponto de vista social) em condiçóes de baixa densidade de tráfego, e estradas pioneiras e até mesmo modernas auto estradas requerem, comparativamente à implantação de novas ferrovias e à construção de sistemas portuários eficientes, tanto custos iniciais menores quanto investimentos de manutenção mais reduzidos.

Como, já no final da primeira metade deste século, a produção industrial se encontrava pesadarnente concentrada em pequena área do território nacional; e como as décadas seguintes testemunharam uma intensificação ainda maior da concentração industrial - de tal sorte que, em 1970, o chamado "Triângulo", São Paulo/Rio/Belo Horizonte, res- 
pondia por cerca de $75 \%$ de toda a produção manufatureira nacional tamanha concentração da produção industrial criou e consolidou vastas áreas dependentes de comércio, sem um feedback significativo de tráfego por parte das chamadas "regióes periféricas", inviabilizando, assim, a possibilidade da implementação de sistemas de transporte altemativos e mais racionais do ponto de vista social.

Não é dificil compreender, em suma, como em paises de dimensão continental, uma excessiva concentração geográfica da produção industrial tende a fazer com que muitas oportunidades para uma eficiente divisão do trabalho permaneçam não utilizadas, tornando mais diffceis as possibilidades para o surgimento de um vigoroso processo de convergência de rendas per capita. Pois, quando as forças produtivas avançam demasiadamente em exíguas seções do território do país, 0 desenvolvimento de outras partes da nação tende a tornar-se cada vez mais difícil, de tal sorte a impedir que se alcance uma divisão ótima do trabalho em nivel nacional. $E$ isto aconteceria porque as vantagens com que contam as áreas mais desenvolvidas tenderiam a viesar o capital e o trabalho na direção de uma crescente concentração de recursos no espaço, tanto através da livre operação das, forças de mercado, quanto pela resistência natural de grupos de pressão localizados nas regióes mais industrializadas no sentido de se promover um processo de desconcentração de atividades econômicas, em geral, e, muito particularmente, de atividades industriais. $O$ resultado desses desniveis agudos de desenvolvimento é o de dificultar a concretização de um verdadeiro processo de integração nacional, bloqueando, como assinalado por Machlup (Machlup, 1977), "a plena utilizaçäo de todas as possibilidades eficientes para a divisão do trabalho [em nivel espacial]" $e$, conseqüentemente, um desejável processo de convergência inter-regional de rendas per capita.

\section{BIBLIOGRAFIA}

ALLEN, K.S. \& MACLENNAN, M.C. Regional Problems and Policies in Italy and France. Londres, George Allen and Unwin, 1970.

BALDWN, R.E. Patterns of Development in Newly Settled Regions. The Manchester School of Economic and Social Studies, v.24, n.2, May, 1956, p.161-79. 
BANCO DO NORDESTE DO BRASIL. ETENE. Desenvolvimento do Nordeste. Diagnóstico e Sugestões de Políticas. Fortaleza, BNB/ETENE, 1978, mimeo.

BNDES. Oportunidades de Investimentos Industriais no Nordeste. Um Enfoque sob a ótica da Descentralização Concentrada. Rio de Janeiro, BNDES, 1986.

BRASIL. IBGE. Censo Industrial de 1919. Recenseamento Geral do Brasil, 1940. Sinopse do Censo Industrial e do Censo de Serviços. Rio de Janeiro, 1948.

- Censo Industrial de 1939. Recenseamento Geral do Brasil, 1940. Sinopse do Censo Industrial e do Censo de Serviços. Rio de Janeiro, 1948.

- Censo Industrial de 1949. VI Recenseamento Geral do Brasil, 1950, v.lll, t.l. Rio de Janeiro, 1957.

- Censo Industrial de 1959. VII Recenseamento Geral do Brasil, 1960. Rio de Janeiro, 1963.

- Censo Industrial de 1970. VIII Recenseamento Geral do Brasil, 1970. Rio de Janeiro, 1973.

- Censos Econômicos. Censo Industrial de 1975. Rio de Janeiro, 1981.

- . Censo Industrial de 1980. Anuário Estatístico do Brasil, 1982. Rio de Janeiro, 1983.

BRITO, F. O Estado Tutelar. O INDI na Experiência Mineira de Industrialização. In: PAIVA, P. (org.) Minas em Questão. Belo Horizonte, CEDEPLAR, 1988, p.55-68.

CAMMACK, P. The Political Economy of the "Politics of the States" Minas Gerais and the Brazilian Federation, 1889-1900. Bulletin of Latin American Research. Oxford, GB, v.2, n.1, Oct. 1982, p.51-65. CENTRO INDUSTRIAL DO BRASIL. O Brasil - Suas Riquezas Naturaes, Suas Indústrias, 1909, 3 vol. (edição fac-simile: Rio de Janeiro, FIBGE, 1986).

DIAS ALEJANDRO, C.F. Argentina, Australia and Brazil before 1929. In: PLATT, D.C.M. \& TELLA, G. (eds.) Argentina, Australia and Canada - Studies in Comparative Development, 1870-1965. Oxford, Macmillan Press, 1974.

DINIZ, C.C. Economia e Planejamento em Minas Gerais - Notas para Discussão. In: PAIVA, P. (org.) Minas em Questão, op.cit., p.3-33.

EISENBERG, P.L. The Sugar Industry in Pernambuco - Modernisation Without Change, 1840-1910. University of California Press, 
USA, 1974.

FOGARTY, J. Staples, Super-Staples and the Limits of Staple Theory.

The Experiences of Argentina, Australia and Canada Compared. In.

PLATT, D.C.M. \& TELLA, G. (eds.). Op.Cit., 1985.

GALLOWAY, J.H. The Sugar Industry of Pernambuco During the 19th

Century. Annals of the American Association of Geographers, v.58, n.2, June 1968, p.285-303.

GALVÂO, Olímpio de A. Regional Development in Brazil. A Study of

Economic Integration in a Unevenly Developed Country. London, 1988. Thesis (dout., econ.), University of London.

. Comércio Inter-regional e Integração dos Mercados no

Brasil, 1943-1969. Recife,' PIMES/UFPE, jun. 1990 (Texto para Discussão n. 220).

HOLLAND, S. Regional Underdevelopment in a Developed Economy:

The Italian Case. Regional Studies, v.5, n.2, p.71-90, 1971.

HOLLOWAY, T.H. Immigrants of the Land-Coffee and Society in São

Paulo, 1886-1934. The University of North Carolina Press, USA, 1980.

KRAVIS, I.B. Trade as a Handmaiden of Growth. Similarities Between the Nineteenth and the Twentieth Centuries. Economic Journal, v.80, Dec. 1970 , p.827-72.

LEFF, N.H. Underdevelopment and Development in Brazil. George Allen \& Unwin, 2v., 1982.

LEVINE, R.M. Pernambuco in the Brazilian Federation, 1889-1937. Stanford University Press, USA, 1978.

MACHLUP, F. History of Thought on Economic integration. GB, MacMillan Press, 1977.

NORTH, D.C. Agriculture in Regional Economic Growth. Journal of Political Economy, v.63, June 1955, p.240-55.

1815-1860. In SUPPLE BE. (ed) The Experience of Economic

Growth - Case Studies in Economic History. New York, Random House, 1963.

PAIVA, P. (org.) Minas em Questão. Belo Horizonte, CEDEPLAR/UFMG, 1988.

PERLOFF, H.S. et alii. Regions, Resources and Economic Growth. Lincoln, University of Nebraska Press, 1965.

PIMES/UFPE. Desigualdades Regionais no Desenvolvimento Brasileiro. Recife, UFPE/IPEA/SUDENE, 1984. 4v. 
PLATT, D.C.M. \& TELLA, G. (eds.) Argentina, Australia and Canada. Studies in Comparative Development, 1870-1965. Oxford, The Macmillan Press, 1985.

SCHIMIDT, L.B. Internal Commerce and Development of National Economy Before 1860. Journal of Political Economy, v.47, n.6, Dec. 1939, p.799-822.

SOLBERG, C.E. Land Tenure and Land Settlement. Policy and Patterns

in the Canadian Praries and the Argentina Pampas, 1880-1930. In: PLATT, D.C.M. \& TELLA, G. (eds.), op.cit., 1985.

SHAPIRO, S.J. \& DOODY, A.F. (eds.) Readings in the Theory of American Marketing - Settlement to Civil War. Illinois, Irwin Inc., 1968.

SUPPLE, B.E. (ed.) The Experience of Economic Growth - Case Studies in Economic History. New York, Random House, 1963.

TAYLOR, G.R. The National Economy in 1860. In: SUPPLE, B.E. op.cit., 1963.

. The Transportation Revolution, 1815-1860. In: SHAPIRO \& DOODY, op.cit., 1968.

TELLA, G. \& PLATT, D.C.M. (eds.) The Political Economy of Argentina, 1880-1946. London, Macmillan Press, 1986.

WATKINS, M.H. A Staple Theory of Economic Growth. The Canadian Journal of Economics and Political Science. v.29, n.2, May 1963, p.141-58.

WRTH, J.B. Minas Gerais in the Brazilian Federation, 1889-1937. Stanford University Press, U.S.A., 1977.

\section{ABSTRACT \\ INDUSTRIAL CONCENTRATION IN BRAZIL ACCORDING TO THE CENSUSES: $1907-1980$}

This paper uses Manufacturing Censuses from 1907 through 1980 in order to examine the evolution of spatial concentration of industry in Brazil. In its various sections, the paper makes comments upon the situation of Brazilian regions at the beginning of the twentieth century; it analyzes the degree of concentration and dispersion of the manufacturing sector at the beginning of the century, based on the Manufacturing Census of 1907, also discussing Brazil's industrial position in terms of other sectors and countries; it.describes the historical evolution of industrial concentration by 'macroregions, and by selected states; and it concludes with some considerations over the consequences of a highly polarizing industrialization process, spatially concentrated in a very small area of the national territory. 